Canadian Journal of Higher Education Revue canadienne d'enseignement supérieur

Volume 46, No. 2, 2016, pages 78 - 91

\title{
Postsecondary Student Mobility from College to University: Academic Performance of Students
}

Kris Gerhardt and Oliver Masakure

Wilfrid Laurier University

\begin{abstract}
This paper considers the impact of transfer credits on the GPA of collegeuniversity transfer students. The data come from the academic records of students enrolled at 2 different campuses at an undergraduate university in Ontario across a 4-year period. The results from multivariate regression analyses show that the number of transfer credits is significantly associated with a higher GPA, controlling for student status (part time/full time), campus of study, cohort, semester of study, and previous college background. Further analysis suggests that the credit-GPA relationship is nonlinear, peaking at 6 transfer credits. These findings can be used to help inform individuals and institutions about the past performance of students as further refinements to transfer policies between institutions are undertaken.
\end{abstract}

\section{Résumé}

Cet article évalue l'effet du transfert de crédits sur la moyenne pondérée cumulative (MPC) des étudiants qui transfèrent des crédits du collège à l'université. Les données proviennent des dossiers académiques d'étudiants de premier cycle inscrits à deux différents campus d'une université ontarienne sur une période de quatre ans. Les résultats d'analyses multivariées régressives montrent que le nombre de crédits transférés est lié de façon significative à une MPC plus élevée, ce qui devient une mesure de contrôle du statut de 
l'étudiant (temps partiel/temps plein), du campus d'étude, de la cohorte, du semestre d'étude et du collège de provenance. Une analyse plus poussée du transfert étudiant collège/université suggère que la relation crédit-MPC n'est pas linéaire et qu'un maximum de six crédits est transféré. Tandis qu'on raffine les politiques de transferts entre établissements, il est possible d'utiliser ces résultats pour mieux informer les individus et les établissements quant à la performance passée des étudiants.

Transfer policies serve to facilitate the enrolment of students into university and are thus one approach to broadening access to university in Canada. Extant research on university performance of transfer students has focused on graduation and dropout rates of transfer students relative to nontransfer students, showing that contrary to some studies (see Nutting, 2011), transfer and nontransfer students tend to have comparable graduation rates (York University, 2007). This parity may be in part because the demographics of transfer students have changed since the early 1990s, and transfer students are becoming more similar to the secondary school cohort with respect to age, gender, and full-time or part-time status. As well, compared to the 1990s, transfer students are entering university with more credits (York University, 2007). Surprisingly, what has been less examined is the academic performance of college transfer students relative to nontransfer students, even though understanding the academic trajectory of students transferring from college is critical to improving Ontario's currently variable college-university transfer policies and enhancing students' university experience.

This study focuses on students transferring from one of a number of different Canadian colleges to a university in Ontario; therefore, results may not be generalizable to other forms of transfer (i.e., university to college; college to college; university to university). The term university is used to refer to institutions most consistently offering 4-year (or more) programs that terminate in a bachelor's degree. The term college is reserved for institutions traditionally offering 2-year programs as well as Colleges of Applied Arts and Technology (CAAT) in Ontario.

Ontario's current college-university transfer policies and student experience vary across universities (Gerhardt, Arai, Carroll, \& Ackerman, 2012), and more research is needed in order to inform policies, such as the Ontario credit transfer system, that are aimed at harmonizing transfer policies and procedures in Ontario. Some universities in Ontario have strengthened their partnerships with colleges to the extent that they are now drawing a sizable proportion of their undergraduate students from colleges (York University, 2007). For example, a study completed at York University in 2007 concluded that, of the new students admitted to the university who did not come from an Ontario secondary school, the numbers of transfer students increased from $19.6 \%$ in 1999 to $30.6 \%$ in 2006. College transfer students, as a proportion of the university's overall student intake, increased from $8.7 \%$ in 1996 to $13.8 \%$ in 2006. The increase in college transfer students is partly due to increasingly stronger collaborations and partnerships between York University and colleges (York University, 2007). Other universities, however, are lagging behind at a time when colleges and universities are being called upon to continually adapt to changing legislation, mandates, and educational environment (Carter, Coyle, \& Leslie, 
2011). Gawley and McGowan (2006) and Carter et al. (2011) suggest that as the number of articulation agreements increase, universities and colleges need to develop core standards with clear institutional support (which includes administrative support) so that they can adequately advise students on and support them with different aspects of the transfer process. These core standards will further inform universities on how to continually improve student pathways to universities and how to develop ways to sustain the ongoing connections and understanding between institutions (Gawley \& McGowan, 2006). Thus, understanding the academic performance of transfer students is paramount, and it is in this context that the present paper examines the effect of transfer credits on students' GPA. The data, covering the period from fall 2008 to fall 2011, comes from students enrolled at a medium-sized university with two different campus locations in southern Ontario.

\section{Literature Review}

There are two strands of literature relevant to this paper. The first relates to studies documenting the evolving nature of articulation agreements between universities and colleges in both the United States and Canada (Carter et al., 2011; Gawley \& McGowan, 2006; Kirby, 2008; Lang, 2007; McGowan \& Gawley, 2006) and the impacts of such agreements on university enrolments (Lang, 2009; Stanyon, 2003; York University, 2007). The second line of research, to which we now contribute, is a small number of studies that consider the academic performance of college-university transfer students (Bell, 1998; College University Consortium Council [CUCC], 2007; Drewes, Maki, Lew, Willson, \& Stringham, 2013; Martinello \& Stewart, 2013; Nutting, 2011; Townsend, McNerny \& Arnold, 1993; Townsend \& Wilson, 2006; York University, 2007).

The literature on articulation agreements suggests that while the changing nature of the educational environment has led to a ratcheting of articulation agreements (McGowan \& Gawley, 2006), the impact on the number of students transferring has been mixed (Lang, 2009; Stanyon, 2003). Articulation/transfer agreements are intended to ease transfers between specific educational programs (Carter et al., 2011) and serve to facilitate enrolment of students from diverse socioeconomic backgrounds into university (Bell, 1998). In contrast to some findings, Lang (2009) concluded that simply increasing the number of articulation agreements will not significantly increase the number of students transferring between institutions. Due to reasons that are both institutional and historical, articulation agreements have tended to vary widely between institutions, with little consistency in implementation (Carter et al., 2011). This is in spite of a common standard for learning expectations being developed in Ontario to help facilitate student transfers (Ontario Ministry of Training, Colleges and University, 2011). While some universities have strengthened college-university partnerships (York University, 2007), agreements in many universities still remain poorly articulated, poorly institutionalized, and as a result inadequately resourced (McGowan \& Gawley, 2006). The lack of core standards and coherence has limited the impact of articulation programs on the number of transfers (Lang, 2009; Stanyon, 2003) and done little to promote the academic success of students posttransfer. Because, in reality, students do not transfer from institution to institution but from program to program, some studies argue that colleges and universities should focus on promoting broader forms of interinstitutional cooperation (Constantineau, 2009; Lang, 2007, 2009). Others argue that universities and colleges should 
devote more resources to deepening institutional support and reversing a long-standing university culture that has traditionally viewed college education and college students themselves as being of lower quality (see Bell, 1998; Carter et al., 2011).

The literature central to the current research has focused on posttransfer academic performance using dropout rates, graduation rates, and GPA as indicators of success. These studies have found that there is increasingly less difference in performance between college transfers and students entering university directly from high school. The lack of significant difference, which has been documented by several studies (CUCC, 2007; Drewes et al., 2013; Martinello \& Stewart, 2013; York University, 2007), suggests changes in the nature of college students over time as well as changes in the number of credits granted to students upon transfer. The prevailing but outdated view in universities is that the college environment and students are so different from a university environment and students that college students lack adequate preparation for university education. These arguments have been used by some members of the university community to justify continued nonrecognition of credits from colleges (Carlan \& Byxbe, 2000). Evidence shows, however, that many credits earned in colleges are comparable to those earned at university (Glass \& Harrington, 2002;), though there remain differences between colleges and universities in faculty teaching function as well as research rigour (Skolnik, 2011).

Studies assessing the performance of college transfers have found a positive relationship between the number of credits completed in college and academic performance in university. These studies have found that college transfer and direct-entry students achieve comparable GPA scores (Bell, 1998; Glass \& Harrington, 2002; Martinello \& Stewart, 2013; Townsend, et al., 1993)and as the demographics of college students become more similar to noncollege transfers, the difference in performance between college and noncollege students continues to narrow (York University, 2007).

A College University Consortium Committee (CUCC) pilot project using data from Nipissing University for transfer and nontransfer students showed that transfer students who received credits tended to choose shorter 3-year degrees, but that there was no significant difference in the credits attempted and failed for the transfer or high school groups (CUCC, 2007). In addition, they found that high school entrants and transfer students had the same GPA (CUCC, 2007). Drewes et al. (2013) assessed academic performance of college students enrolling at Trent University and found that college transfers performed as well as nontransfers in terms of GPA; also, dropout rates among the transfer students were lower than those of high school entrants. Martinello and Stewart (2013) used data from Brock University and found that transfer students did not differ from nontransfer students in rates of academic suspension or cumulative GPA.

Previous research has compared the graduation rates of transfer and nontransfer students (Bell, 1998; CUCC, 2007). Some studies found that transfer students struggled to graduate at the same rate as nontransfer students and tended to graduate with a 3-year (15 credit) rather than a 4-year (20 credit) degree (Bell, 1998; Martinello \& Stewart, 2013). Research suggests that the predominant reasons for these results are the competing demands on older transfer students and the pressure to go back to work at the earliest opportunity (Matinello \& Stewart, 2013). In slight contrast, a study at York University, which has significantly strengthened its transfer policies, found that fewer transfer students are dropping out compared to the 1990 (York University, 2007), and since 1999 a significant pro- 
portion of transfer students are graduating after 4 and 5 years. At the same time, transfer credits, which provide students with advanced standing, increase graduation rates because transfer students with advanced standing are less likely to drop out than transfer students without advanced standing (Bell, 1998). A concern in all these studies is self-selection. That is, all students in these studies have chosen to attend university, and therefore may be systematically different from other college students. However, due to paucity of data, studies have not been able to control for self-selection (see Martinello \& Stewart, 2013).

Overall these studies suggest that college students should be encouraged to make the transfer (Martinello \& Stewart, 2013), and while a system-wide wholesale transfer policy is not perhaps the optimal policy, the fact that transfers do as well as nontransfers supports past and current efforts to build partnerships with and pathways from the college system (Drewes et al., 2013). Thus, to the extent that a key policy objective of public sector higher education is to optimize the fit between student interests and available programs, articulation along program lines seems to be an effective option because more students end up being where they want to be (Lang, 2009). As Ontario's transfer credit agenda moves forward, more empirical evidence is required regarding the performance of college students transferring to university programs. Indeed, while more studies on the number of transfer students graduating on schedule and the number of transfer students graduating overall are required (Martinello \& Stewart, 2013), there is clearly a need for more studies on other measures of academic success. The present research focuses on cumulative GPA as one such measure of academic success.

\section{The Credit Transfer System in Ontario}

Transfer credits are defined as courses completed at one (originating) institution being awarded credit at another (destination) institution, such that these credits may be applied to an eventual certificate, diploma, or degree (Ontario Council on Articulation and Transfer [ONCAT], 2016). In Ontario, there are currently a number of accepted methods or policies for transferring credits, and therefore individual institutions have devised their own policies and procedures around transfer (Gerhardt et al., 2012; ONCAT, 2016). Under the traditional credit transfer model, students receive program credit when transferring from one postsecondary institution to another, regardless of the type of institution involved (college to college, university to college, college to university, or university to university). In many cases, colleges and universities have intertransfer agreements that formalize credit recognition, but students frequently transfer from colleges to universities even without such agreements. In such cases, the individual negotiates with the institution, and the recognition of credits is far less efficient and advantageous to the student relative to situations where an articulation agreement exists at the institutional level (Kirby, 2008).

Transfer credits may be awarded on a course-by-course basis, such that the destination institution looks at different factors including course content, grade achieved, and date of course completion in order to ascertain whether a course from the originating institution can be considered equivalent. In the case where a course from the originating institution is deemed equivalent, credit for that specific course would be given at the destination institution and the student would be treated as if they had completed that course as part of their degree requirements (if a student was transferring to a university). 
Another way of assessing transfer credits is the "block credit" transfer model (ONCAT, 2016). In this model, the destination institution looks at groups of courses in an originating program and decides how many specific and how many general credits to award a student who has successfully completed a program. Block credit transfers allow admission to university programs without the course-by-course comparisons in articulation agreements (Carter et al., 2011). General credits are usually applied to elective course requirements and therefore lower the number of electives a transfer student would have to take to meet their specific degree requirements. Factors such as marks achieved in individual courses and across a program, as well as the date of completion, may also be taken into account. The more closely aligned a destination program is to an originating (and completed) program, the more transfer credits may be assessed (ONCAT, 2013), but once again, in Ontario each institution has its own policies so the determination of credits is made on a case-by-case basis (Gerhardt et al., 2012).

It is important to note that the average number of transfer credits provided to college students transferring to universities is roughly equivalent to one full academic year (two semesters) of study, though some schools have transfer credit policies that have no real effect on the expected graduation date (i.e., only a few courses are given university credit, and the policy is used more as a metric for admission), while others require only two or three additional terms of full-time study for an honours degree (Gerhardt et al., 2012).

\section{Method}

The student-level data used in the present analysis came from administrative records of a sample of college transfer and nontransfer students enrolled at a medium-sized university in southern Ontario. This university has a main (original) and satellite campus. The main campus (hereafter Campus A) uses a more traditional course-by-course analysis to determine transfer credits, while the satellite campus (hereafter Campus B) employs a comprehensive block credit transfer policy that was introduced in 2009. The data cover the period from the fall 2008 semester to fall 2011. We used data from all the transfer and nontransfer students.

The GPA scores from the point of entry were used for each student. The data had multiple semesters for each student, and thus the data had both longitudinal and crosssectional features. For the analysis, only fall and winter semesters were used because few students take spring and summer courses. For each cohort, we had the following number of semesters: seven for 2008, five for 2009, and three for 2010.

The data contained each student's GPA by semester, enrollment status, the campus at which the student was enrolled, and the total credits earned for college transfers. We also had information on the college from which the student originated, and all the nontransfer students were assumed to have come directly from high schools. Credit transfers (0.5 credits equal to a one-semester course) were granted in the first semester on entering university and, as will be explained below, dictated the type of regression analysis feasible. The main disadvantage of this type of student record data was the limited number of control variables that could be used in the GPA equation due to confidentiality reasons. While the data pertained to only arts students, it was not possible to include students' information on race/ ethnicity, gender, age, or specific program of study, since these data were not released with the original deidentified data set. While these data limitations are common (see Drewes et al., 2013), they restrict the nature of analyses and conclusions that can be drawn. 
The absence of information on a wide range of demographic and other factors that potentially impact academic performance raises three econometric issues. The first is related to the students' GPA measure. The main focus of the current analysis was the difference in student GPA conditional on the number of transfer credits received. Because of the way the data were gathered and stored, it was not possible, in the present study, to gather raw GPA on a semester-by-semester basis, and therefore the GPA data obtained, while longitudinal, were cumulative. Thus, aside from the first GPA of each cohort, subsequent GPA were serially correlated. The second problem with data on college transfers in general is that college students self-select into university. While being accepted into a program is likely to be independent of family background, it is not independent of student ability. This issue has been raised before (see Martinello \& Stewart, 2013) and is difficult to correct without more detailed but confidential data. The third issue concerns omitted variable bias. If regressions do not control for individual specific unobserved variables such as personality traits (academic environment, motivation, etc.) that jointly positively influence GPA and the program of study, then the coefficient on the number of credits may be upwardly biased.

The data issues raised above are commonly handled using panel data methods (Cameron \& Trivedi, 2005; Wooldridge, 2002). It is, however, not feasible to use a fixed effects model which would allow us to control for unobserved heterogeneity because transfer credits are only granted once when the student transfers from college. Remember that the key variable is the number of transfer credits. If a fixed effects model is used, the number of transfer credits would drop out of the regressions because it is invariant throughout the student's tenure at university. Thus the most appropriate approach is a random effects (RE) model given the panel structure of our data. Even though it does not control for unobserved heterogeneity, the RE model can accommodate both time-constant and time-varying regressors. The $\mathrm{RE}$ regression equation takes the form

$$
\begin{aligned}
& \mathrm{GPA}_{\mathrm{it}}=\alpha_{\mathrm{i}}+\text { Credits }_{\mathrm{i}} \lambda+X_{\mathrm{it}}^{\prime} \beta+\mu_{\mathrm{it}} \\
& \text { where } \left.X_{\text {it }}^{\prime}=\text { [Semester }{ }_{\text {it }} \text {, Fulltime }{ }_{\text {it }} \text {, Campus }{ }_{\text {it }} \text {, PrevColl }{ }_{\mathrm{i}} \text {, Cohort }{ }_{\mathrm{i}}\right]
\end{aligned}
$$

In the above equations the dependent variable is the GPA of the $i$ th student in semester $t$. The variable Credits is the number of transfer credits. The $\alpha_{\mathrm{i}}$ is an unobserved timeconstant individual effect, and the vector $X^{\prime}$ includes controls for semester of enrollment, full-time status, and campus. In addition, because random effects accommodate time-invariant regressors, we included PrevColl for previous college fixed effects and Cohort $_{\mathrm{i}}$ for cohort $\left(2008,2009\right.$, or 2010) fixed effects with $\mu_{\mathrm{it}}$ the error term.

One key advantage of the RE model is that it yields estimates of all coefficients and hence marginal effects, even those of time-invariant regressors. The main assumptions of the random effects model are that $\alpha_{\mathrm{i}}$ and $X_{\mathrm{it}}{ }_{\mathrm{it}}$ are independent, Credits ${ }_{\mathrm{i}}$ and $X_{\mathrm{it}}{ }_{\mathrm{it}}$ are strictly exogenous, and the unobserved effects are normally distributed with $\alpha_{\mathrm{i}} \sim \mathrm{N}\left[\mathrm{O}, \sigma_{\alpha}^{2}\right]$. This assumes that the individual specific effects are uncorrelated with the independent variables, but this is too strong an assumption. This disadvantage can, however, be remedied by applying robust standard errors that are clustered around the individual (see Cameron \& Trivedi, 2005). 


\section{Results and Discussion}

In Table 1 we present the descriptive statistics showing the mean GPA, the number of credit transfers received, the status of the student and the campus of enrollment and their cohort.

Table 1.

Descriptive Statistics for Variables used in Regression Analysis

\begin{tabular}{|c|c|c|c|c|}
\hline & Mean & $S D$ & Min. & Max. \\
\hline GPA & 7.138 & 2.334 & 1 & 12 \\
\hline \#Transfer Credits & 1.880 & 2.394 & o & 12.5 \\
\hline \#Transfer Credits ${ }^{2}$ & 18.478 & 18.566 & 0.25 & 156.25 \\
\hline Transfer student $=1$ if a transfer student & 0.501 & 0.500 & o & 1 \\
\hline Fulltime $=1$ if full-time student & 0.750 & 0.433 & o & 1 \\
\hline Campus $B=1$ if enrolled in Campus $B$ & 0.434 & 0.458 & o & 1 \\
\hline Block Credit = 1 if student received Block credits & 0.433 & 0.495 & o & 1 \\
\hline 2008 Cohort $=1$ if student was in 2008 cohort & 0.423 & 0.329 & o & 1 \\
\hline 2009 Cohort $=1$ if student was in 2009 cohort & 0.363 & 0.481 & o & 1 \\
\hline 2010 Cohort $=1$ if student was in 2010 cohort & 0.212 & 0.409 & o & 1 \\
\hline
\end{tabular}

Table 2 displays the results of the random effects models. The data for the 2008, 2009, and 2010 cohorts were stacked up before we estimated the link between GPA and number of credits received. The controls included a campus location dummy variable and whether the student was part time or full time. In addition, dummy variables for semester of study and cohort were included to capture semester fixed effects and cohort effects. We also controlled for the college from which the students transferred, and for nontransfer students we coded them as all high school. Given that the institution of study can act as a proxy for quality and other factors, this last variable was meant to capture aspects of the student's past educational profile.

The results in column 1 show that our variable of interest, the number of transfer credits, was highly significant and positive with a magnitude of 0.11 . This suggests that one credit was associated with an $11 \%$ increase in GPA. The dummy variables for transfer status and campus were positive and highly significant. There was no evidence from the regressions that full-time students tended to perform better than part-time students. We find found no evidence of a cohort effect on GPA.

It was also important to know if transfer status or the number of transfer credits was the primary route by which GPA differed for transfer students. In order to tease this out, we estimated the regressions with a dummy variable for whether the student was a transfer or not but omitted the number of transfer credits. The results, in column 2, are not surprising. We found that being a transfer student is associated with a higher GPA, suggesting that both the number of credits and transfer status are driving the results, though the number of credits has a stronger effect. 
Table 2.

Random Effects Regression Results: Dependent Variable Is Cumulative GPA

\begin{tabular}{|c|c|c|c|c|c|c|}
\hline Variable & Model 1 & Model 2 & Model 3 & Model 4 & Model 5 & Model 6 \\
\hline \#Credits & $\begin{array}{c}0.114^{* *} \\
(2.67)\end{array}$ & & $\begin{array}{l}0.0145 \\
(0.19)\end{array}$ & $\begin{array}{l}0.166 \\
(1.78)\end{array}$ & $\begin{array}{l}0.457^{* * * *} \\
(3.37)\end{array}$ & $\begin{array}{l}0.656^{* * * *} \\
(3.57)\end{array}$ \\
\hline \# Credits ${ }^{2}$ & & & & & $\begin{array}{l}-0.0392^{* *} \\
(-2.93)\end{array}$ & $\begin{array}{l}-0.0550^{* *} \\
(-2.86)\end{array}$ \\
\hline Transfer student & $\begin{array}{l}0.977^{* * *} \\
(2.97)\end{array}$ & $\begin{array}{c}1.056^{*} \\
(2.25)\end{array}$ & $\begin{array}{c}0.650^{*} \\
(1.98)\end{array}$ & $\begin{array}{c}-3.095^{* * *} \\
(-12.75)\end{array}$ & & \\
\hline Fulltime & $\begin{array}{r}0.189 \\
(1.42)\end{array}$ & $\begin{array}{r}0.176 \\
(1.32)\end{array}$ & $\begin{array}{c}-0.486 \\
(-1.92)\end{array}$ & $\begin{array}{l}0.532^{* *} \\
(3.20)\end{array}$ & $\begin{array}{c}0.254 \\
(1.88)\end{array}$ & $\begin{array}{l}0.544^{* *} \\
(3.25)\end{array}$ \\
\hline Campus B & $\begin{array}{l}0.992^{* * * *} \\
(9.50)\end{array}$ & $\begin{array}{l}1.022^{* * * *} \\
(9.85)\end{array}$ & & & $\begin{array}{l}1.049^{* * * *} \\
(5.44)\end{array}$ & \\
\hline 2009 Cohort & $\begin{array}{c}0.455 \\
(1.87)\end{array}$ & $\begin{array}{l}0.464 \\
(1.91)\end{array}$ & $\begin{array}{c}0.745 \\
(1.95)\end{array}$ & $\begin{array}{r}0.271 \\
(0.86)\end{array}$ & $\begin{array}{c}0.481 \\
(1.39)\end{array}$ & $\begin{array}{c}0.582 \\
(1.27)\end{array}$ \\
\hline 2010 Cohort & $\begin{array}{l}0.0587 \\
(0.23)\end{array}$ & $\begin{array}{l}0.0860 \\
(0.34)\end{array}$ & $\begin{array}{l}0.0246 \\
(0.06)\end{array}$ & $\begin{array}{c}0.233 \\
(0.68)\end{array}$ & $\begin{array}{c}0.340 \\
(0.90)\end{array}$ & $\begin{array}{l}0.595 \\
(1.17)\end{array}$ \\
\hline Semester fixed effects & $\# 15$ & $\# 15$ & $\# 15$ & $\# 15$ & $\# 15$ & $\# 15$ \\
\hline $\begin{array}{l}\text { College (previous) } \\
\text { fixed effects }\end{array}$ & $\# 41$ & $\# 41$ & $\# 41$ & $\# 41$ & $\# 41$ & $\# 41$ \\
\hline Constant & $\begin{array}{c}6.065^{* * * *} \\
(25.18)\end{array}$ & $\begin{array}{c}6.052^{* * * *} \\
(25.04)\end{array}$ & $\begin{array}{c}6.769^{* * * *} \\
(17.53)\end{array}$ & $\begin{array}{c}6.626^{* * *} \\
(22.12)\end{array}$ & $\begin{array}{c}6.719^{* * * *} \\
(16.01)\end{array}$ & $\begin{array}{l}2.446^{* * * *} \\
(5.13)\end{array}$ \\
\hline$R^{2}$ within & 0.1228 & 0.1200 & 0.1562 & 0.0949 & 0.1719 & 0.1594 \\
\hline$R^{2}$ overall & 0.1239 & 0.1212 & 0.1618 & 0.0954 & 0.1728 & 0.1632 \\
\hline$N$ & 2585 & 2585 & 1120 & 1465 & 1297 & 805 \\
\hline
\end{tabular}

Note. The 2008 Cohort is the omitted category. Parentheses indicate $t$ statistics. ${ }^{*} p<.05 .{ }^{* *} p<.01 .{ }^{* * *} p<.001$.

While our data lacked information on the age of the students, we could not rule out the possibility that the age effect was being disguised as a transfer credit effect. There is a general notion that transfer students are older, more mature, and more focused. It is also generally assumed that college transfer students are a homogeneous group. However, focus groups conducted as part of the research project (Gerhardt et al., 2012) showed that the transfer students were a diverse group, with unique needs and challenges. Even among those we can call "mature students," there was diversity of needs and challenges. For example, some college transfers who identified themselves as mature were still living with their parents, while others who identified themselves as mature had children and family responsibilities. These group differences also influenced how students sought and used information and made their course selections. Yet mature students interviewed in the focus groups shared one common attitude towards their academic life at university. Unlike younger high school students, who are more likely to use university as a place to explore a variety of life opportunities and choices, mature students tend to be more focused, determined, and serious about their studies and have a strong desire to succeed. 
In addition, mature students face challenges that are specific to their courses. For example, students who transfer to similar programs (i.e., transferring from college to university but remaining within the same discipline or field, such as college students studying finance who transfer to a university business program) face unique challenges with regard to course material that overlaps between college and university. In contrast, students who transfer into alternative programs (i.e., students who choose a field of study in university very different from what they did in college, such as college students studying finance who transfer to a university arts program) face an entirely different set of challenges, in particular grappling with the new expectations regarding writing assignments. In addition, international students face problems that include language and culture barriers, financial obstacles, and the applicability of previous educational experiences. Thus the transfer credit variable may have captured the effect of age as well as other factors varying within the mature student group, such as field of study.

It is possible that the results were being driven by the campus of study. Recall that the transfer programs used in the two campuses are not entirely similar. While Campus A uses a more traditional course-by-course analysis to determine transfer credits, Campus $B$ uses a comprehensive block credit transfer policy. In order to explicitly ascertain the extent to which the campus of study was influencing the results, we split the data by campus and re-estimated the models in columns 3 and 4 . The results in columns 3 and 4 suggest that the campus of study was not driving all the results. In column 3, where we estimated the GPA of students in Campus A only, we see that the number of transfer credits was not statistically significant, with the same result for Campus B in column 4.

The results suggest that each additional transfer credit raised the GPA score, but it was also important to know if this effect was as true for the first transfer credit as the tenth. One way to assess this is to include a squared term for the number of credits. A nonlinear specification was, however, not possible with the whole sample because students directly from high school do not get transfer credits, so that the number of their credits is zero. Thus we estimated a nonlinear random effects regression using college transfer students only, so that the nonlinear specification was comparing GPA performance among transfer students only. In order to avoid multicollinearity between the original variable (\#Credits) and its quadratic term (\#Credits ${ }^{2}$ ), we also first centred the \#Credits variable before we created the square term (\#Credits ${ }^{2}$ ). However, this did not make any difference to the variance inflation factor, so we present results without centring the \#Credits variable. The results, presented in columns 5 and 6, show that the number of transfers (\#Credits) had a positive and statistically significant impact on GPA among transfer students with coefficients of 0.457 and 0.656 respectively. In addition, we should expect the \#Credits ${ }^{2}$ variable to be negative because the relationship between GPA and squared term (\#Credits ${ }^{2}$ ) should be concave. As would be expected the \#Credits ${ }^{2}$ variable was negative and statistically significant with coefficients of -0.0392 and -0.0550 in columns 5 and 6 respectively. Remember the \#Credits variable was positive, suggesting that the number of credits had a positive effect on GPA until a turning point was reached. We can interpret this as follows for column $5: 0.457 /(2 \times 0.0392)=5.83$ and for column 6: $0.656 /(2 \times 0.0550)=5.96$. Though limited to transfer students, this result suggests the potential costs of granting students too many transfer credits. That is, transfer credits had a positive effect on GPA up to 6 credits, but beyond that value transfer credits had a negative effect on GPA. Note that the maximum number of transfer credits in the data was 12.5 with a mean of 1.88 . 
We can think of at least two reasons why a concave relationship between GPA and number of credits may arise. First, it could be that students are getting more transfer credits that add no value to their learning or getting credits that do not prepare them well for advanced courses. This was a theme that came out of focus group sessions (Gerhardt et al., 2012). Several students who had received 7 or more transfer credits mentioned using their credits in place of junior-level courses, only to find in fourth year that they needed specific skills that hadn't been a part of their college education. Others mentioned being somewhat overwhelmed when trying to figure out how to use their transfer credits and how to apply them to their current degree program. In one case a student mentioned that they used only 4.5 of an available 7 transfer credits because of the need to take required courses or courses they personally felt were essential to take. This particular student mentioned feeling quite bitter that they had accepted an offer to this institution based solely on the number of transfer credits and then couldn't use them all. Second, it is also possible that more transfer credits may cause students to overestimate their ability, leading them to put less effort into their studies, thus impacting their academic performance. Future studies should consider the impact of awarding students more transfer credits than they can realistically use in acquiring their university degree and the impact of negative perceptions that some students may develop when they realize that more is not necessarily better.

\section{Limitations}

The 2008 cohort was the oldest data set collected and as such, the current research was not able to appropriately assess graduation rates. Only two of the 2008 sample had applied to graduate at the time the data were obtained from the registrar. Future studies should consider gathering data from cohorts to a minimum of 6 years before the date of collection to ensure that graduation rates could be obtained in sufficient numbers to allow for in-depth comparisons.

Given the lack of data on demographics such as age, race, gender, socioeconomic status, and specific programs of study, our results may suffer from omitted variables bias and as such should be considered tentative and interpreted with caution. We cannot draw substantive conclusions about the role of the college-to-university transfer credit system on students' GPA performance. Indeed, while the lack of detailed personalized data is a common issue when accessing data from student academic records, it does limit the number of questions that can be investigated.

\section{Conclusion and Recommendations}

The impact of transfer credits on the academic performance of transfer students is an important area of research that will serve to further inform the discussion around articulation and transfer policy agreements. Although the current research is unable to investigate certain demographic characteristics (age, race, socioeconomic status, etc.) or the impact of on-campus student service programs due to the limitations in the current data set, the analysis provides insights in a number of areas. First is that future studies should be conducted on the same issue using rich data, and especially also consider the role of different transfer credit systems and how they are applied in universities with multiple campuses. As well future research should attend to the differences in student service programs and their impact on transfer students. 
The regression analysis suggests that students awarded transfer credits tend to perform better than students straight from high school, but the results do not suggest a causal link and need to be interpreted with caution given the limited controls we had at our disposal. In addition, our analysis of the transfer students' data suggests that the relationship between transfer credits and GPA is nonlinear, peaking at 6 transfer credits. This result suggests that it is important to consider the marginal impact of transfer credits. However, given the nature of the data and their limitations as indicated above, and the study's focus on one multicampus university, it will be important that more studies are conducted to validate these and other previous results.

While the demographics of transfer students now closely resemble those of high school entrants, other factors such as personal motivation and program of choice should be investigated in an effort to explain their role in student performance. In addition, some universities are continuing to strengthen their relationships with colleges, and some have made significant investments in college transfer programs. The nature of articulation agreements between universities and colleges tends to vary across campuses and programs. More specifically, the two university campuses considered in this paper provide different levels of support to transfer students, which may have a bearing on the performance of transfer students as indicated in Table 2. At a more general level, the institutional and environmental effect may equally be important in the performance of transfer students at other multicampus universities. We recommend that more research be conducted to tease out this institutional effect.

As the government of Ontario continues to pressure postsecondary institutions to refine the transfer process for students, the results of the current study will help to inform institutions on both side of the transfer process to enable them to adapt and create policies that, while maintaining the integrity of each institution, help to serve the best interests of the students involved.

\section{Acknowledgements}

The authors gratefully acknowledge CUCC/ONCAT for financial assistance in support of this research project.

\section{References}

Bell, S. (1998). College transfer students: A Canadian case. Community College Journal of Research and Practice, 22(1), 21-37.

Cameron, A. C., \& Trivedi, P. K. (2005). Microeconomics: Methods and applications. Cambridge, UK: Cambridge University Press.

Carlan, P. E., \& Byxbe, F. R. (2000). Community colleges under the microscope: An analysis of performance predictors for native and transfer students. Community College Review, 28, 27-42.

Carter, I., Coyle, J., \& Leslie, D. (2011). Easing the transfer students from college to university programs: How can learning outcomes help? Community College Journal of Research and Practice, 22(1), 21-37. 
CollegeUniversityConsortiumCouncil(CUCC).(2007).Measuringthesuccessofcollege transfer students and Nipissing University, 1994-2005 (Final Report). Retrieved from http://oncat.ca/files_docs/content/pdf/en/oncat_research_reports/oncat_research_ reports_17.pdf

Constantineau, P. (2009). The Ontario transfer credit system: A situation report (COU No. 817). Retrieved from Council of Ontario Universities website: http://cou.on.ca/ papers/the-ontario-transfer-credit-system/

Drewes, T., Maki, K., Lew, K., Willson, M., \& Stringham, K. (2013, January). An analysis of CAAT transfer students' academic performance at Trent University. Paper presented at the Student Pathways in Higher Education Conference, Toronto, ON.

Gawley, T., \& McGowan, R. A. (2006). Learning the ropes: A case study of the academic and social experiences of college transfer students within a developing universitycollege articulation framework. College Quarterly, 9(3), Retrieved from http://www. senecacollege.ca/quarterly/2006-volo9-numo3-summer/gawley_mcgowan.html.

Gerhardt, K., Arai, B., Carroll, M., \& Ackerman, M. (2012). Postsecondary student mobility: From college to university: Experience and policy. Toronto, ON: Ontario Council on Articulation and Transfer. Retrieved from http://www.oncat.ca/files_docs/ content/pdf/en/oncat_research_reports/2012-12-Laurier-Postsecondary-studentmobility-college-university-experience-policy.pdf

Glass, J. C., \& Harrington, A. R. (2002). Academic performance of community college transfer students and "native" students at a large state university. Community College Journal of Research and Practice, 26, 413-430.

Kirby, D. (2008). Advancing articulation: Models of college university collaboration in Canadian higher education. College Quarterly, 11(4), Retrieved from http://www. senecacollege.ca/quarterly/2008-vol11-numo4-fall/kirby.html XX-XX.

Lang, D. W. (2007). The effects of articulation on college choice. College Quarterly, 1O(4), Retrieved from http://www.senecacollege.ca/quarterly/2007-vol10-numo4-fall/ lang.html.

Lang, D. W. (2009). Articulation, transfer, and student choice in a binary postsecondary system. Higher Education, 57, 355-371. doi:10.1007/s10734-008-9151-3

Martinello, F., \& Stewart, J. (2013, January). Transfers from college to university: A four-year outcome study. Paper presented at the Student Pathways in Higher Education Conference, Toronto, ON.

McGowan, R. A., \& Gawley, T. (2006). The university side of the college transfer experience: Insights from university staff. College Quarterly, 9(3), Retrieved from http:// www.senecacollege.ca/quarterly/2006-volo9-numo3-summer/mcgowan_gawley.html.

Nutting, A. (2011). Community college transfer students' probabilities of baccalaureate receipt as a function of their prevalence in four year colleges and departments. Education Economics, 19(1), 65-87.

Ontario Council on Articulation and Transfer (ONCAT). (2016.) Credit Transfer in Ontario. Retrieved from https://www.ontransfer.ca/index_en.php?page=credit_ transfer_in_ontario Retrieved April 14, 2016 
Ontario Ministry of Training, Colleges and University. (2011). Policy statement for Ontario's credit transfer system. Retrieved from http://www.tcu.gov.on.ca/eng/ document/document.html

Skolnik, M. (2011). Reconceptualizing the relationship between community colleges and universities using a conceptual framework drawn from the study of jurisdictional conflict between professions. Community College Review, 39(4), 352-375. doi:10.1177/0091552111424205

Stanyon, W. (2003). College university collaboration: An Ontario perspective. College Quarterly, 6(1), . Retrieved from http://www.senecacollege.ca/quarterly/2003-volo6numo1-fall/stanyon.html.

Townsend, B. K., McNerny, N., \& Arnold, A. (1993). Will this community college transfer student succeed? Factors affecting transfer student performance. Community College Journal of Research and Practice, 17(5), 433-443. doi:10.1080/0361697930170504

Townsend, B. K., \& Wilson, K. (2006). "A hand hold for a little bit": Factors facilitating the success of community college transfer students to a large research university. Journal of College Student Development, 47(4), 439-456. doi:10.1353/csd.2006.0052

Wooldridge, J. (2002). Econometric analysis of cross section and panel data. Cambridge, MA: MIT Press.

York University. (2007). An analysis of undergraduate students admitted to York University from an Ontario College of Applied Arts and Technology (CAAT) between 1996 and 2006. Retrieved from ONTransfer website: http://www.ontransfer.ca/www/ files_docs/content/pdf/en/oncat_research_reports/oncat_research_reports_16.pdf

\section{Contact Information}

Kris Gerhardt

Leadership Program

Wilfrid Laurier University, Brantford Campus

kgerhardt@wlu.ca

Kris Gerhardt is an associate professor in the Leadership and Psychology programs at the Brantford Campus of Wilfrid Laurier University. His research focuses on curriculum design and the prevalence of communication skills courses in postsecondary academic programming.

Oliver Masakure is an associate professor in the Business Technology Management Program at the Brantford Campus of Wilfrid Laurier University. His research focuses on economic development, labour economics, and the economics of food and health. 